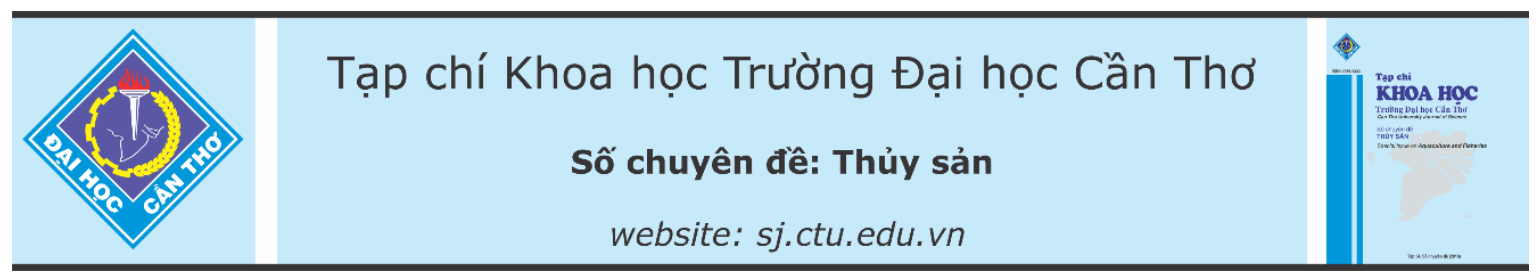

DOI: $10.22144 /$ ctu.jsi.2020.043

\title{
SO SÁNH MỘT SỐ CHỈ TIÊU SINH SẢN GIŨ̃a CÁC NGUỒN CÁ TRÊ VÀNG (Clarias macrocephalus)
}

Dương Thúy Yên ${ }^{1 *}$, Nguyễn Thanh Tuấn ${ }^{2}$, Nguyễn Thị Thanh Nhàn ${ }^{3}$, Nguyễn Thị Ngọc Trân ${ }^{1}$, Nguyễn Hồng Quyết Thắng ${ }^{1}$ và Nguyễn Thanh Hiệu ${ }^{1}$

${ }^{1}$ Khoa Thủy Sản, Truờng Đại học Cần Tho

${ }^{2}$ Lớp Cao hoc quốc tế K3, Khoa Thủy Sản, Truờng Đại học Cần Tho

${ }^{3}$ Lớp Nuôi Trồng Thủy Sản K40, Khoa Thủy Sản, Truờng Đại hoc Cần Tho

*Nguoòi chịu trách nhiệm về bài viết: Duoong Thúy Yên (email: thuyyen@ctu.edu.vn)

\section{Thông tin chung:}

Ngày nhận bài: 21/10/2019

Ngày nhận bài sủa: 04/11/2019

Ngày duyệt đăng: 23/04/2020

\section{Title:}

Comparing reproductive parameters among broodstock sources of bighead catfish (Clarias macrocephalus)

\section{Tù khóa:}

Anh hương con mẹ, cá trê vàng, lai chéo, nguồn cá, sinh sản

\section{Keywords:}

Bighead catfish, broodstock sources, intraspecific hybridization, maternal effects, reproduction

\begin{abstract}
The study aimed to evaluate effects of different broodstock sources on reproductive traits and larval development of bighead catfish. Three broodstock sources including two wild populations (Ca Mau, CM and Long An, LA) and one cultured population (Can Tho, CT) were conditioning cultured for three months. When the fish got the maturation stage, six to nine pairs of breeders from each source were artificially produced in nine reciprocal crosses. CM females had the lowest relative fecundity $(25,700$ eggs $/ \mathrm{kg})$ with the highest egg diamter $(1.77 \mathrm{~mm})$, significantly different from those of LA and CT sources (57,000 to 60,800 eggs/ $\mathrm{kg}$ and $1.68 \mathrm{~mm}$, respectively).

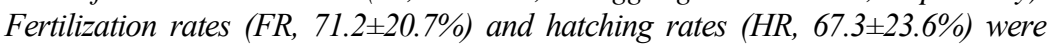
affected by females sources $(P<0.01$ for $H R)$ but not by males $(P>0.05)$. The highest $F R$ and HR were found in CM female crosses. Yolk sac absorption lasted for 54 to 60 hrs. post hatch. Larval sizes at hatch and in five days differed among male and females sources and nine crosses $(P<0.01)$. Larval length was significantly highest in $C M$ and lowest in CT sources. There were no statistical differences in FR, $H R$, and larval sizes between pure and intraspecific crosses within the same female sources $(P>0.05)$.
\end{abstract}

\section{TÓM TẮT}

Nghiên cưu nhằm đánh giá ảnh hưởng của các nguồn cá cá trê vàng bố me đến các chỉ tiêu sinh sản và sư phát triển của cá bột. Ba nguồn cá bố me gồm 2 nguồn cá tư nhiên ở Cà Mau (CM) và Long An (LA) và nguồn 1 nuôi ở Cần Tho (CT) được nuồi vố ba tháng. Khi cá đạt giai đoạn thành thục, 6 đến 9 cặp cá tù mỗi nguồn được lai chéo theo 9 tổ hợp. Kết quả cho thấy cá cái $C M$ có sức sinh sản thục tế thấp nhất (25.700 trứng/kg) nhưng đường kính trứng lớn nhất $(1,77$ mm), khác biệt có ý nghĩa $(P<0,01)$ so với cá $L A$ và $C T$ (tuoong úng 57.000 đến 60.800 trứng/ $/ \mathrm{kg}$ và $1,68 \mathrm{~mm})$. Tỉ

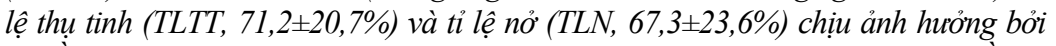
nguồn cá cái $(P<0,01$ cho TLN) nhung khác biệt không có ý nghĩa giũa các nguồn cá đụcc $(P>0,05)$. TLTT và TLN cao nhẩt ở nguồn cá cái $C M$. Thòi gian hấp thu noãn hoàng dao động tù 54 đến 60 giờ: Kích cỡ cá bột lúc nở và trong 5 ngày đầu khác biệt thống kê $(P<0.01)$ giũa các nguồn cá cái, nguồn cá đực và 9 tổ hợp. Chiều dài cá bột lón nhất là cá CM và thấp nhẩt là cá CT. TLTT, TLN và kích cỡ cá bột khác biệt không có ý nghĩa giữa tổ hợp thuần và lai trong cùng một nguồn cá cái $(P>0,05)$.

Trích dẫn: Dương Thúy Yên, Nguyễn Thanh Tuấn, Nguyễn Thị Thanh Nhàn, Nguyễn Thị Ngọc Trân, Nguyễn Hồng Quyết Thắng và Nguyễn Thanh Hiệu, 2020. So sánh một số chỉ tiêu sinh sản giữa các nguồn cá trê vàng (Clarias macrocephalus). Tạp chí Khoa học Trường Đại học Cần Thơ. 56(Số chuyên đề: Thủy sản)(2): 94-101. 


\section{GIỚI THIỆU}

Cá trê vàng (Clarias macrocephalus) là loài cá nước ngọt có giá trị kinh tế cao và là đối tượng nuôi quan trọng ở Việt Nam cùng một số nước Đông Nam Á khác (Na-Nakorn and Brummett, 2009). Ở Đồng bằng sông Cửu Long, cá trê vàng đã được sản xuất giống và nuôi thành công từ những năm 1980, song phong trào ít phát triển so với cá trê vàng lai (C. macrocephalus x Clarias gariepinus) do chúng tăng trưởng chậm và tỉ lệ sống trong ương, nuôi thấp. Tại những thời điểm nuôi cá trê lai phát triển mạnh (Dương Thúy Yên và $c t v ., 2017)$, cá trê vàng chủ yếu được nuôi để phục vụ cho sản xuất giống cá trê lai. Tuy nhiên, do loài cá này là nguồn thực phẩm được ưa chuộng và trước thực trạng nguồn lợi tự nhiên ngày càng cạn kiệt (Lê Nguyễn Ngọc Thảo và ctv., 2017), rất cần thiết có những nghiên cứu cải thiện hiệu quả trong ương, nuôi cá trê vàng. Một trong những giải pháp là thực hiện các chương trình chọn giống.

Trong chọn giống thuỷ sản, thông tin về các chỉ tiêu sinh sản từ các nguồn cá bố mẹ khác nhau là cần thiết vì những chỉ tiêu này thường biến động giữa các dòng, các quần thể trong cùng một loài (Dunham, 2011). Thông tin về các chi tiêu sinh sản của cá trê vàng đã được nhiều tài liệu đề cập (Phạm Minh Thành và Nguyễn Văn Kiểm, 2009; Dương Nhựt Long và $c t v ., 2014)$ nhưng sự khác biệt giữa các nguồn cá bố mẹ đến các chi tiêu trên chưa được báo cáo. Vì vậy, nghiên cứu này đánh giá ảnh hưởng của các nguồn cá trê vàng bố mẹ có nguồn gốc nuôi và tự nhiên đến các chi tiêu sinh sản và sự phát triển ban đầu của đàn con, để cung cấp thông tin cho chương trình chọn giống cá trê vàng.

\section{PHƯƠNG PHÁP NGHIÊN CÚU}

Nghiên cứu được thực hiện từ tháng 04/2018 đến tháng 09/2018 tại Khoa Thủy sản, Trường Đại học Cần Thơ.

\subsection{Nguồn cá thí nghiệm và nuôi vỗ}

Nguồn cá trê vàng được chọn gồm: (i) cá tự nhiên thu từ vườn Quốc gia U Minh Hạ, Cà Mau (CM); (ii) cá tự nhiên ở khu bảo tồn Đất ngập nước Láng Sen, Long An (LA); và (iii) cá nuôi tập hợp từ 3 trại giống khác nhau ở Cần Thơ $(\mathrm{CT})$.

Cá được thu vào tháng 4/2018 với số lượng 20 $30 \mathrm{~kg} / \mathrm{nguồn}$. Cá đực và cái từ mỗi nguồn được tách riêng, thả vào bể $1 \mathrm{~m}^{3}$ được thiết kế trong hệ thống tuần hoàn. Cá được cho ăn thức ăn viên công nghiệp chứa $40 \%$ đạm, ngày 2 lần (sáng 8 giờ và chiều 17 giờ) với liều lượng $1-2 \%$ tổng khối lượng cá trong bể. Thời gian nuôi vỗ là 3 tháng.

\section{2 Đánh giá các chỉ tiêu sinh sản và lai} chéo của 3 nguồn cá trê vàng

Chuẩn bị cho cá sinh sản: chọn được 9 cặp cá trê vàng từ mối nguồn Cà Mau và Cần Thơ (riêng nguồn Long An có 6 cặp) có độ thành thục tốt để chuẩn bị cho sinh sản. Cá được chọn dựa vào đặc điểm bên ngoài: cá cái có bụng to mềm, lỗ sinh dục màu hồng và có hình vành khăn; cá đực có cơ thể thon, gai sinh dục nhọn và có màu hồng. Mỗi cá thể đều được cân khối lượng và được bố trí từng cặp riêng vào thùng nhựa (thể tích $40 \mathrm{~L}$ ), chứa nước từ 20-30 cm. Sau đó, cá được kích thích sinh sản.

Kích thích nhân tạo cá trê vàng: cá bố mẹ được kích thích sinh sản bằng hormone HCG kết hợp với não thùy cá chép. Đối với cá cái, hormone được tiêm hai liều: liều sơ bộ dùng HCG với liều $500 \mathrm{UI} / \mathrm{kg}$ cá cái. Khoảng $7-8$ giờ sau, cá cái được tiêm liều quyết định với liều 3.500 UI (HCG) và $2 \mathrm{mg}$ não thùy. Cá đực chỉ tiêm một lần (ở thời điểm tiêm lần hai cho cá cái) với liều 1,500 UI/kg. Liều lượng kích thích tố đều sử dụng như nhau cho cả ba nguồn cá.

Nghiệm thức: thí nghiệm gồm 9 tổ hợp (hay nghiệm thức) sinh sản và lai chéo từ 3 nguồn cá (Bảng 1).

\section{Bảng 1: Các tổ hợp sinh sản}

\begin{tabular}{|c|c|c|c|}
\hline Nguồn cá cái & $\begin{array}{l}\text { Nguồn cá đục Cà Mau } \\
(\mathrm{N}=9)\end{array}$ & $\begin{array}{l}\text { Cần Tho' } \\
(\mathrm{N}=9)\end{array}$ & $\begin{array}{l}\text { Long An } \\
(\mathrm{N}=6)\end{array}$ \\
\hline Cà Mau $(\mathrm{N}=9)$ & $\mathrm{CM}$ & CMxCT & CMxLA \\
\hline Cần Thơ $(\mathrm{N}=9)$ & СТхCM & $\mathrm{CT}$ & CTxLA \\
\hline Long An $(\mathrm{N}=6)$ & LAxCM & LAxCT & LA \\
\hline
\end{tabular}

Trứng (cân khối lượng sau khi vuốt) và tinh (chia theo thể tích) của mỗi con được thu và chia đều làm ba phần. Trứng của mỗi con cái được thụ tinh với tinh trùng (giữ lạnh trong thùng đá) của ba con đực ở ba nguồn khác nhau và ngược lại (Bảng 1$)$. Trứng sau khi thụ tinh được khử dính và được ấp trong bình jar theo từng nghiệm thức.

Song song đó, trứng thụ tinh từ mỗi con cái được lấy ngẫu nhiên khoảng 100 -150 trứng (lập lại 3 lần) và ấp trong khay nhựa có kích thước $16 \times 10 \times 5 \mathrm{~cm}$ có 
hệ thống nước nhỏ giọt để tính tỷ lệ nở, tỷ lệ thụ tinh. Trong quá trình ấp trứng, theo dõi nhiệt độ bằng nhiệt kế và đo hai lần trong một ngày.

Các chỉ tiêu sinh sản được thu gồm: tỉ lệ cá sinh sản, sức sinh sản thực tế, kích thước trứng sau thụ tinh, tî̉ lệ thụ tinh, tỉ lệ nở, được tính theo các công thức sau:

Tỉ lệ cá sinh sản $(\%)=$ (Số cá sinh sản / tổng cá tham gia sinh sản) x 100 .

Sức sinh sản thực tế (trứng $/ \mathrm{kg}$ cá cái) = Số lượng trứng cá sinh sản /khối lượng cá sinh sản $(\mathrm{kg})$.

Kích thước trứng sau thụ tinh: trứng sau khi thụ tinh được lấy ngẫu nhiên $30-50$ trứng để đo đường kính trứng. Trứng được đo trên kính hiển vi.

Tỉ lệ thụ tinh $(\%)=$ (Số trứng thụ tinh / số trứng quan sát )x 100.

Tỉ lệ nở $(\%)=$ (Số trứng nở / số trứng thụ tinh )x 100.

\subsection{Sự phát triển của cá bột sau năm ngày sau khi nở}

Cá bột từ mỗi tổ hợp lai chéo (Bảng 1) được bố trí trong xô nhựa (2 lần lặp lại) có thể tích $20 \mathrm{~L}$ và sục khí liên tục. Các xô được đặt trong trại hở, có lưới che. Mật độ thả cá là $15 \mathrm{con} / \mathrm{L}$. Thời gian tiêu hóa hết noãn hoàng được theo dõi bằng cách thu mẫu cá bột 12 giờ/ lần trong 3 ngày liên tiếp sau khi nở. Ngày thứ 3 , cá được cung cấp thêm thức ăn bên ngoài là Moina. Sự phát triển của cá được xác định bằng cách thu mẫu hàng ngày vào lúc 8 giờ sáng và đo ngẫu nhiên 20 - 30 cá thể/xô.

\subsection{Phương pháp xử lý số liệu}

Ảnh hưởng của nguồn cá và kích cỡ con cái cùng với sự tương tác của hai yếu tố này lên các chỉ tiêu sinh sản và kích thước cá bột được phân tích bằng phương pháp "General linear models". Khi ảnh hưởng của nguồn cá có ý nghĩa $(\mathrm{P}<0.05)$, sự khác biệt giữa các nguồn cá được kiểm định bằng phương pháp phi tham số "Dunn test" và giá trị $\mathrm{p}$ được điều chỉnh cho so sánh nhiều nhóm theo phương pháp Benjamini-Hochberg (Dinno, 2015). Tỉ lệ thụ tinh và tỷ lệ nở được phân tích giữa hai yếu tố là nguồn cá cái và nguồn cá đực, tương tự như phương pháp nêu trên. Xử lý số liệu được thực hiện bằng chương trình R (R Core Team, 2017).

\section{KẾT QUẢ}

\subsection{So sánh một số chỉ tiêu sinh sản của 3 nguồn cá trê vàng}

\subsubsection{Thời gian hiệu ứng và tỉ lệ cá rụng trứng}

Trong thời gian cho cá sinh sản, nhiệt độ dao động trong khoảng 28 đến $30^{\circ} \mathrm{C}$. Bể ấp và ương cá được sục khí liên tục nên đảm bảo oxy hòa tan $(>5$ $\mathrm{ppm}$ ) thích hợp cho sự phát triển của phôi và cá bột. Trong điều kiện trên, thời gian hiệu ứng trung bình của cá ở ba nguồn dao động từ 11 giờ đến 12 giờ (Bảng 2). Đa số cá cái tự nhiên ở Cà Mau và Long An rụng trứng sớm hơn cá nuôi ở Cần Thơ, tuy thời gian chênh lệch không đáng kể (trong một giờ). Theo Phạm Minh Thành và Nguyễn Văn Kiểm (2009) thời gian hiệu ứng thuốc của cá có liên quan chặt chẽ với mức độ thành thục của cá và nhiệt độ của môi trường nước. Giữa các loài cá trê, thời gian hiệu ứng cũng khác nhau, so với cá trê vàng là 11 12 giờ, cá trê Phú Quốc lâu hơn, 16 - 17 giờ ở nhiệt độ $29-30^{\circ} \mathrm{C}$ (Phạm Thanh Liêm và $\left.c t v ., 2015\right)$.

Bảng 2: Thời gian hiệu ứng, tỉ lệ rụng trứng, sức sinh sản tương đối và thời gian phát triển phôi của 3 nguồn cá trề vàng

\begin{tabular}{|c|c|c|c|}
\hline Chỉ tiêu & Cà Mau N = 9 & Cần Tho $\mathrm{N}=9$ & Long An N = \\
\hline Khối lượng cá cái (g) & $247 \pm 59^{\mathrm{b}}$ & $231 \pm 61^{b}$ & $162 \pm 20^{\mathrm{a}}$ \\
\hline Thời gian hiệu ứng (giờ) & $11^{\mathrm{h}} 5^{\prime}$ & $12^{\mathrm{h}}$ & $11^{\mathrm{h}} 5^{\prime}$ \\
\hline Tỉ lệ sinh sản (\%) & 77,8 & 77,8 & 83,3 \\
\hline Sức sinh sản (trứng/kg) & $25.700 \pm 6.273^{\mathrm{a}}$ & $60.796 \pm 20.720^{\mathrm{b}}$ & $56.950 \pm 18.760^{\mathrm{b}}$ \\
\hline Đường kính trứng $(\mathrm{mm})$ & $1,77 \pm 0,18^{\mathrm{b}}$ & $1,68 \pm 0,11^{\mathrm{a}}$ & $1,68 \pm 0,12^{\mathrm{a}}$ \\
\hline Thời gian phát triên phôi (giờ) & 23 giờ $10 \mathrm{ph}$ & 22 giờ $58 \mathrm{ph}$ & 24 giờ $20 \mathrm{ph}$ \\
\hline
\end{tabular}

Ghi chú: Các giá trị trong cùng một hàng có chũ cái giống nhau thì khác biệt không có ý nghĩa thống kê $(P>0,05)$

Tỉ lệ cá rụng trứng ở ba nguồn cá dao động từ 77,8 - 83,3\% (Bảng 2). Tỉ lệ ở mức cao, tương đương với nghiên cứu khác trên cá trê vàng, tỉ lệ rụng trứng đạt 66,3 - 79,6\% ( Nguyễn Văn Kiểm và
Lam Mỹ Lan, 2017). Tỉ lệ rụng trứng cao nhất ở nguồn cá Long An. Thời gian phát triển phôi của cá không có sự chênh lêch lớn giữa 3 nguồn cá, dao động từ 23 giờ đến 24 giờ 20 phút. 


\subsubsection{Súc sinh sản và đuoòng kính trúng sau} khi thu tinh của ba nguồn cá cái trê vàng

Cá cái tham gia sinh sản có khối lượng từ $124 \mathrm{~g}$ đến $335 \mathrm{~g}$, cá Cà Mau và Cần Thơ lớn hơn có ý nghĩa so với cá Long $A n(\mathrm{P}<0,01)$ (Bảng 2). Mỗi con có số trứng vuốt được dao động từ 4.200 đến 19.900 trứng, tương đương với 18.400 - 95.000 trứng/ $\mathrm{kg}$ cá cái. Kết quả này có khoảng dao động lớn hơn so với những báo cáo trước, sức sinh sản của cá trê vàng thường dao động $40.000-80.000$ trứng $/ \mathrm{kg}$ cá cái (Phạm Minh Thành và Nguyễn Văn Kiểm, 2009; Dương Nhựt Long và ctv., 2014).

Sức sinh sản thực tế của ba nguồn cá khác biệt có ý nghĩa thống kề $(\mathrm{P}<0,05)$, trong đó thấp nhất là nguồn cá Cà Mau (trung bình $~ 25.700$ trứng/ $\mathrm{kg}$ cá cái) và cao nhất là nguồn cá Cần Thơ $(\sim 60.800$ trứng/kg cá cái). Sức sinh sản của cá Long An (
57.000 trứng/kg cá cái) khác biệt không có ý nghĩa so với cá Cần Thơ $(\mathrm{P}>0,05)$. Trong cùng một nguồn cá $(\mathrm{NC})$, khối lượng cá cái $(\mathrm{Wc})$ có ảnh hưởng đến sức sinh sản $\mathrm{P}>0,05$ ) nhưng không giống nhau giữa các nguồn, nghĩa là có sự tương tác có ý nghĩa $\left(\mathrm{P}_{\mathrm{NCxWc}}<0,05\right)$ giữa khối lượng cá cái và nguồn cá lên sức sinh sản thực tế của cá (Hình 1). Cá Cà Mau và Cần Thơ có xu hướng giảm sức sinh sản thực tế khi khối lượng tăng (tương ứng giảm 230 và 730 trứng/ $\mathrm{kg}$ cá cái cho mỗi $10 \mathrm{~g}$ tăng về khối lượng) và cá Long An có xu hướng ngược lại. Tuy nhiên, do số mẫu ít nên mối quan hệ này cần được thực hiện trên số mẫu nhiều hơn. Ở cá rô đồng, mối quan hệ nghịch giữa khối lượng cá cái và sức sinh sản tương sản tương đối (số trứng trong buồng trứng ở giai đoạn IV $/ \mathrm{kg}$ cá cái) thể hiện chặt chẽ hơn (hệ số gốc $=-1,38, \mathrm{R}^{2}=0,60$ ) (Dương Thúy Yên và Phạm Thanh Liêm, 2014).

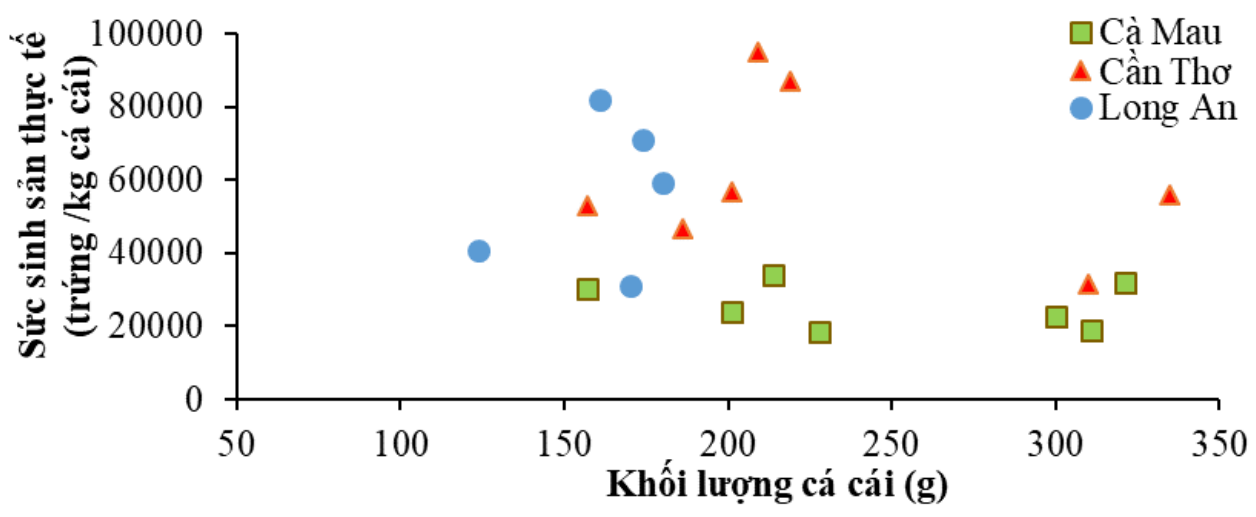

Hình 1: Sức sinh sản thực tế của ba nguồn cá trê với khối lượng cá cái khác nhau

Đường kính trứng trong nghiên cứu này được đo sau khi khử dính, lúc này trứng đã trương nước và có đường kính trung bình từ $1,68 \mathrm{~mm}$ đến $1,77 \mathrm{~mm}$ (Bảng 2). Kết quả này cao hơn so với các báo cáo trước, đường kính trứng cá trê từ $1,10-1,30 \mathrm{~mm}$ (Phạm Minh Thành và Nguyễn Văn Kiểm, 2009; Dương Nhựt Long và $c t v .$, 2014). Sự khác biệt này có thể chủ yếu do thời điểm thu mẫu trứng (trước hoặc sau thụ tinh) khác nhau.

Đường kính trứng khác biệt có ý nghĩa giữa ba nguồn cá $(\mathrm{P}<0,01)$. Trong đó, cá Cà Mau có đường kính trứng lớn nhất $(1,77 \mathrm{~mm})$, cá Cần Thơ và Long An có đường kính trứng tương đương nhau $(1,68$ $\mathrm{mm}$ ). Cùng một nguồn cá, các con cái khác nhau có kính thước trứng khác nhau (ảnh hưởng của con mẹ là rất có ý nghĩa, $\mathrm{P}<0,01)$. Cá cái có khối lượng càng cao đường kính trứng càng lớn nhưng với mức độ tăng rất nhỏ (hệ số gốc $=3,5 \times 10^{-4} ; \mathrm{R}^{2}=0,013$; $\mathrm{P}<0,01$ ) và khác nhau giữa các nguồn cá (tương tác có ý nghĩa giữa khối lượng và nguồn cá, $\mathrm{P}<0,01)$.
Đường kính trứng cũng có mối quan hệ tỉ lệ nghịch nhưng ở mức rất nhỏ với sức sinh sản của cá cái (hệ số gốc $\left.=-1,4 \times 10^{-6} ; \mathrm{R}^{2}=0,030 ; \mathrm{P}<0,01\right)$ trong cùng một nguồn. Mối quan hệ nghịch này càng thể hiện rõ khi so sánh giữa 3 nguồn cá cái. Cá Cà Mau có sức sinh sản thực tế thấp nhất nhưng kích thước trứng cao nhất, khác biệt rất có ý nghĩa $(\mathrm{P}<0,01)$ so với hai nguồn cá Cần Thơ và Long An. Mối quan hệ trên gọi là mối quan hệ bù trừ (trade-off), có ý nghĩa về mặt sinh học và tiến hóa, cá cái "đầu tư" năng lượng cho số lượng trứng nhiều phải "hy sinh" giảm kích thước trứng với mục tiêu tăng số lượng đàn con và kết quả là cá sẽ có kích thước trứng tối ưu (Einum and Fleming, 2000; Parker and Begon, 1986).

\section{Tỉ lệ thụ tinh và tỉ lệ nở ở chín tổ hợp sinh sản}

Tỉ lệ thụ tinh (TLTT) trung bình của chín tổ hợp sinh sản (Hình 2) là $71,2 \pm 20,7 \%(\mathrm{~N}=57)$ và không có sự khác biệt thống kê giữa các nguồn cá cái $(\mathrm{P}=0,24)$ hay cá đực $(\mathrm{P}=0,77)$. Tuy nhiên, giữa các nguồn cá cái có sự chênh lệch, cá cái Cà Mau và Cần 
Thơ có TLTT trung bình là $76 \%$ so với $62 \%$ ở cá Long An. Trong cùng một nguồn cá cái, tổ hợp thuần có TLTT (trung bình 78,1 113,4\%) cao hơn tổ hợp lai $(70,4 \pm 21,1 \%)$ nhưng không có ý nghĩa $(\mathrm{P}=0,14)$. Kết quả khác biệt lớn nhưng không có ý nghĩa thống kê giữa các nguồn cá cái hay giữa tổ

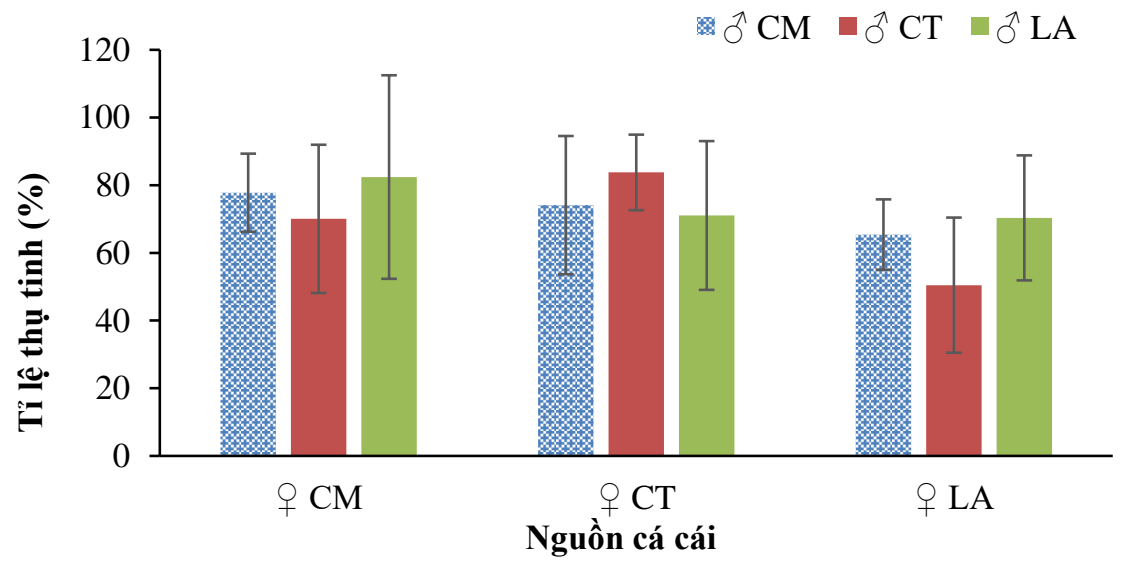

Hình 2: Tỉ lệ thụ tinh ở các tổ hợp lai giữa ba nguồn cá Cà Mau $(\mathrm{CM})$, Cần Thơ $(\mathrm{CT})$ và Long An (LA)

Tỉ lệ nở trung bình của các gia đình đạt $67,3 \pm$ $23,6 \%$, thấp nhất từ $11,6 \%$ đến cao nhất $99,0 \%$. TLN khác biệt có ý nghĩa giữa các nguồn cá cái $(\mathrm{P}=0.017)$ nhưng không khác biệt thống kê theo nguồn cá đực $(\mathrm{P}=0,79)$ hay theo tổ hợp lai $(\mathrm{P}=0,38)$. Giữa các nguồn cá cái, TLN cao nhất ở cá cái Cà Mau (79,0 $20,1 \%)$, khác biệt có ý nghĩa so với hai nguồn cá Cần Thơ $(58,0 \pm 18,7 \%)$ và Long $\mathrm{An}$ $(60,7 \pm 30,0 \%)$. Trong cùng nguồn cá cái, các tổ hợp thuần và lai có TLN tương đương nhau (tương ứng là $66,0 \%$ và $68,8 \%$ ).

TLTT và TLN trong thí nghiệm này đạt tương đương đến cao hơn với nghiên cứu trước. Theo Nguyễn Văn Kiểm và Lam Mỹ Lan (2017), cá trê hợp thuần và lai, chủ yếu do có sự chênh lệch lớn giữa các cá thể. Tỉ lệ thụ tinh thấp nhất là $26,3 \%$ và cao nhất trong thí nghiệm là $97,1 \%$. Tỉ lệ các gia đình (cặp cái $\mathrm{x}$ đực) có tỉ lệ thụ tinh $>70 \%$ chiếm $64,2 \%$, nhưng cũng có $20,1 \%$ gia đình đạt $<40 \%$.

$$
\widehat{\jmath} \mathrm{CM}=\hat{\jmath} \mathrm{CT}=\hat{\jmath} \mathrm{LA}
$$

vàng trong thí nghiệm các loại kích thích tố sinh sản khác nhau, cho TLTT và TL nở dao động trong khoảng tương ứng $20,7-88,8 \%$ và $17,8-93,8 \%$. Trên cá trê phi, TLN được báo cáo tương đối thấp, từ $28,4 \%$ đến $59,1 \%$ (de Graaf et al., 1995). Kết quả trong nghiên cứu cho thấy TLTT và TLN không phụ thuộc vào nguồn con đực mà phụ thuộc chủ yếu vào nguồn con cái. Điều này có thể do mức độ thành thục của con đực tương đối đồng đều hơn con cái. Hai chỉ tiêu này tương đương giữa tổ hợp thuần và tổ hợp lai cùng nguồn con cái, chứng tỏ lai chéo không làm ảnh hưởng đến TLTT và TLN. Kết quả này được giải thích là do các nguồn cá cùng một loài, chúng không có cơ chế cách ly sinh sản dẫn đến TLTT và TLN thấp như lai khác loài (Dunham, 2011).

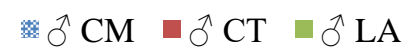

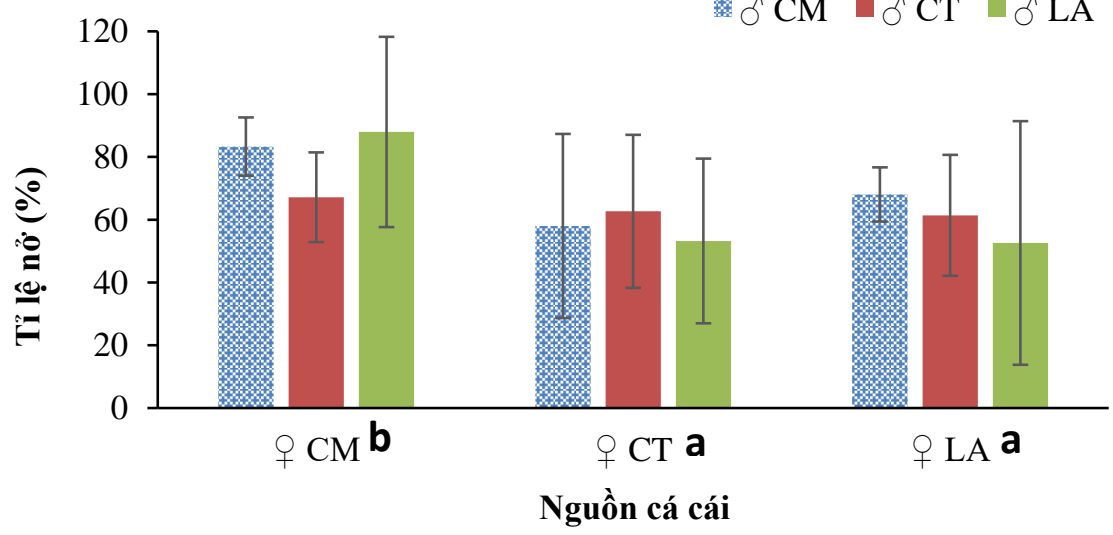

Hình 3: Tỉ lệ nở ở các tổ hợp lai giữa ba nguồn cá Cà Mau (CM), Cần Thơ (CT) và Long An (LA)

(Ghi chú: nguồn cá cái có chũ theo sau giống nhau thì khác biệt không có ý nghĩa, P>0,05) 


\subsection{Chiều dài cá mới nở đến năm ngày tuổi}

Nhiệt độ trong 5 ngày thí nghiệm dạo động từ 27 đến $31^{\circ} \mathrm{C}$. Ở khoảng nhiệt độ này, thời gian tiêu thụ noãn hoàng từ 54 đến 60 giờ sau khi nở. Trong ương nuôi cá trê vàng, người ta thường cho cá ăn ngoài từ 3 ngày sau khi nở (Dương Nhựt Long và $c t v$., 2014). Chiều dài cá mới nở dao động từ 3,34-3,61 mm và giữa các nghiệm thức khác biệt có ý nghĩa thống kê $(\mathrm{P}<0,05)$. Nguồn cá cái ảnh hưởng rất có ý nghĩa $(\mathrm{P}<0,01)$ đến kích cỡ cá mới nở. Tổ hợp từ cá cái Cà Mau có chiều dài mới nở lớn nhất

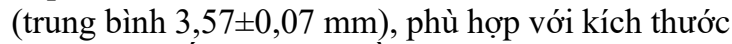
trứng lớn nhất so với cá Cần Thơ $(3,47 \pm 0,1 \mathrm{~mm})$ và Long An $(3,47 \pm 0,11 \mathrm{~mm})$.

Một ngày sau khi nở, cá tăng trưởng rất nhanh, chiều dài trung bình là $6,0 \mathrm{~mm}$, tăng $2,5 \mathrm{~mm}$, hay tăng 1,7 lần so với lúc mởi nở. Sau đó, tốc độ tăng trưởng chậm hơn, ở ngày thứ hai và ba, cá tăng 0,33 đến $0,36 \mathrm{~mm}$ và ngày thứ tư và năm, cá tăng 1,0 đến $1,2 \mathrm{~mm}$, đạt chiều dài trung bình từ $8,3-9,1 \mathrm{~mm}$ (Hình 4).

Chiều dài của cá mới nở và trong năm ngày đầu (Bảng 3) khác biệt thống kê giữa các tổ hợp sinh sản $(\mathrm{P}<0,01)$ và thứ tự tổ hợp $(\mathrm{TH})$ cá lớn nhất có sự thay đổi theo ngày $\left(\mathrm{P}_{\text {NgàyxTH }}<0,01\right)$. Khi xét $\mathrm{xu}$ hướng chung trong thời gian theo dõi, ảnh hưởng của nguồn cá cái và cá đực lên tăng trưởng của đàn con là rất có ý nghĩa $(\mathrm{P}<0,01)$, chúng đều thể hiện xu hướng cá Cà Mau $>$ cá Long $A n>$ Cá Cần Thơ (Hình 4). Trong cùng một nguồn cá cái, không có sự khác biệt thống kê giữa cá thuần và cá lai $(\mathrm{P}=0,81)$.

Chiều dài của cá mới nở có liên quan chặt chẽ với kích thước trứng và chịu ảnh hưởng của con mẹ (Einum and Fleming, 1999; Heath et al., 1999; Einum and Fleming, 2000). Dưới ảnh hưởng của con mẹ, các tổ hợp sinh sản từ nguồn cá cái Cà Mau có kích thước trứng lớn nhất, kích thước cá bột với nở cũng như tăng trưởng của cá trong 5 ngày đầu đều cao hơn so với hai nguồn cá còn lại. Kết quả tương tự cũng được báo cáo trên cá rô, cá rô tự nhiên thu ở Cà Mau có kích thước trứng và chiều dài cá mới nở lớn hơn so với cá rô nuôi (cá rô "đầu vuông") và cá rô tự nhiên từ nơi khác (Dương Thúy Yên và Dương Nhựt Long, 2013). Theo Dunham (2011), ảnh hưởng của con mẹ chỉ tồn tại ở thời gian đầu trong vòng đời và thời gian ảnh hưởng khác nhau tùy vào loài cá. Ở cá trê vàng, nghiên cứu này chỉ theo dõi cá trong năm ngày nên chưa xác định được thời gian ảnh hưởng. Ở cá rô, ảnh hưởng của con mẹ mất đi khi cá con ở 25 - 35 ngày tuổi (Dương Thúy Yên và Dương Nhựt Long, 2013).

\section{Bảng 3: Chiều dài cá bột $(\mathrm{cm})$ của các tổ hợp lai khác khau sau 5 ngày tuổi}

\begin{tabular}{lrrrrrr}
\hline Nghiệm thức & Mới nở & Ngày 1 & Ngày 2 & Ngày 3 & Ngày 4 & Ngày 5 \\
\hline $\mathrm{CM} \times \mathrm{CM}$ & $3,61 \pm 0,06^{\mathrm{e}}$ & $6,1 \pm 0,7^{\mathrm{ab}}$ & $6,4 \pm 0,5^{\mathrm{a}}$ & $6,6 \pm 0,5^{\mathrm{ab}}$ & $7,9 \pm 0,7^{\mathrm{ab}}$ & $9,1 \pm 0,6^{\mathrm{d}}$ \\
$\mathrm{CM} \times \mathrm{CT}$ & $3,53 \pm 0,07^{\mathrm{de}}$ & $5,7 \pm 0,5^{\mathrm{a}}$ & $6,2 \pm 0,6^{\mathrm{a}}$ & $6,6 \pm 0,5^{\mathrm{ab}}$ & $8,2 \pm 0,6^{\mathrm{b}}$ & $8,8 \pm 0,7^{\mathrm{bcd}}$ \\
$\mathrm{CM} \times \mathrm{LA}$ & $3,56 \pm 0,10^{\mathrm{de}}$ & $5,8 \pm 0,7^{\mathrm{ab}}$ & $6,3 \pm 0,5^{\mathrm{a}}$ & $6,8 \pm 0,3^{\mathrm{ab}}$ & $7,8 \pm 0,6^{\mathrm{ab}}$ & $9,1 \pm 0,6^{\mathrm{d}}$ \\
$\mathrm{CT} \times \mathrm{CM}$ & $3,34 \pm 0,12^{\mathrm{a}}$ & $5,9 \pm 0,4^{\mathrm{ab}}$ & $6,2 \pm 0,5^{\mathrm{a}}$ & $6,5 \pm 0,4^{\mathrm{a}}$ & $7,7 \pm 0,7^{\mathrm{ab}}$ & $8,3 \pm 0,7^{\mathrm{ab}}$ \\
$\mathrm{CT} \times \mathrm{CT}$ & $3,44 \pm 0,13^{\mathrm{bc}}$ & $6,2 \pm 0,7^{\mathrm{ab}}$ & $6,4 \pm 0,5^{\mathrm{a}}$ & $6,5 \pm 0,4^{\mathrm{ab}}$ & $7,5 \pm 0,6^{\mathrm{a}}$ & $8,5 \pm 0,5^{\mathrm{abc}}$ \\
$\mathrm{CT} \times \mathrm{LA}$ & $3,60 \pm 0,09^{\mathrm{e}}$ & $5,8 \pm 0,6^{\mathrm{ab}}$ & $6,1 \pm 0,5^{\mathrm{a}}$ & $6,4 \pm 0,4^{\mathrm{a}}$ & $7,5 \pm 0,5^{\mathrm{a}}$ & $8,1 \pm 0,6^{\mathrm{a}}$ \\
$\mathrm{LA} \times \mathrm{CM}$ & $3,51 \pm 0,07^{\mathrm{cd}}$ & $6,4 \pm 0,8^{\mathrm{b}}$ & $6,9 \pm 0,7^{\mathrm{b}}$ & $7,3 \pm 0,63^{\mathrm{c}}$ & $7,9 \pm 0,8^{\mathrm{ab}}$ & $8,9 \pm 0,4^{\mathrm{cd}}$ \\
$\mathrm{LA} \times \mathrm{CT}$ & $3,40 \pm 0,13^{\mathrm{ab}}$ & $5,8 \pm 0,35^{\mathrm{ab}}$ & $6,4 \pm 0,4^{\mathrm{a}}$ & $6,9 \pm 0,2^{\mathrm{b}}$ & $7,5 \pm 0,4^{\mathrm{a}}$ & $8,7 \pm 0,5^{\mathrm{bcd}}$ \\
$\mathrm{LA} \times \mathrm{LA}$ & $3,52 \pm 0,10^{\mathrm{cd}}$ & $5,9 \pm 0,7^{\mathrm{ab}}$ & $6,3 \pm 0,5^{\mathrm{a}}$ & $6,6 \pm 0,5^{\mathrm{ab}}$ & $8,0 \pm 0,5^{\mathrm{ab}}$ & $8,7 \pm 0,6^{\mathrm{bcd}}$ \\
\hline
\end{tabular}

Ghi chú: Giá trị trong cùng một cột theo sau bởi các chũ cái giống nhau thì khác biệt không có ý nghĩa thống kê $(P>0,05)$ 


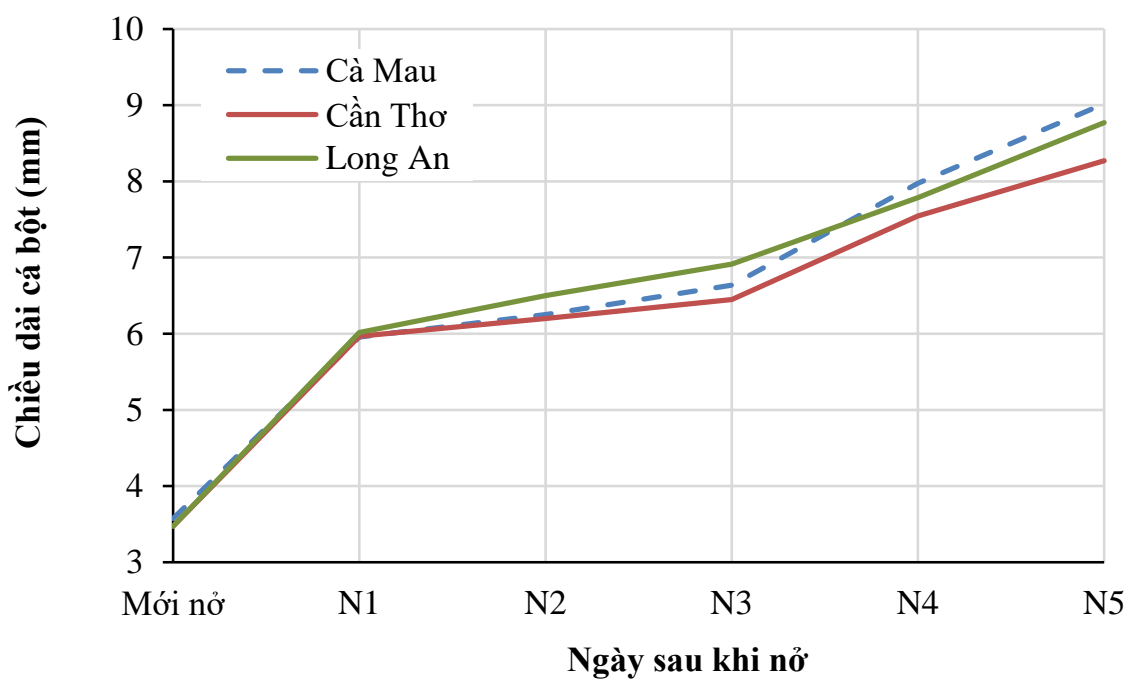

Hình 4: Chiều dài trung bình của cá ở các tổ hợp sinh sản từ ba nguồn cá cái từ khi mới nở đến 5 ngày tuổi

\section{KẾT LUẬn VÀ ĐỀ XUẤT}

\subsection{Kết luận}

Các chỉ tiêu sinh sản gồm tỉ lệ sinh sản, sức sinh sản, kích thước trứng, tî lệ thụ tinh và tỉ lệ nở khác biệt giữa các nguồn cá bố mẹ, chủ yếu là ảnh hưởng của con cái. Cá cái ở Cà Mau có sức sinh sản thực tế thấp nhất, song có nhiều ưu điểm về tỉ lệ thụ tinh, tỉ lệ nở, đường kính trứng, chiều dài cá mới nở và sự phát triển của cá con trong năm ngày đầu. Sức sinh sản tương đối có xu hướng tỉ lệ nghịch với kích cỡ cá cái và đường kính trứng.

Cùng một nguồn cá cái dù có sự khác biệt lớn về kích cỡ giữa các cá thể nhưng không có sự khác biệt thống kê về một số chỉ tiêu sinh sản và kích cỡ của cá con giữa tổ hợp lại thuần và lai chéo.

\section{2 Đề xuất}

Nghiên cứu cần tiếp tục trên các nguồn cá trê vàng khác nhau và với số mẫu nhiều hơn để có đủ thông tin phục vụ cho chương trình chọn giống cá trê vàng.

\section{LỜI CẢM TẠ}

Nghiên cứu này được tài trợ bởi Dự án Nâng cấp Trường Đại học Cần Thơ VN14-P6 bằng nguồn vốn vay ODA từ chính phủ Nhật Bản. Nhóm tác giả chân thành cảm ơn một số sinh viên Khoa Thủy sản đã hỗ trợ trong quá trình thực hiện nghiên cứu.

\section{TÀI LIỆ THAM KHẢO}

de Graaf, G.J., Galemoni, F., Banzoussi, B., 1995. Artificial reproduction and fingerling production of the African catfish, Clarias gariepinus
(Burchell 1822), in protected and unprotected ponds. Aquac. Res. 26: 233-242.

Dinno, A., 2015. Nonparametric pairwise multiple comparisons in independent groups using Dunn's test. Stata J.

Dunham, R., 2011. Aquaculture and fisheries biotechnology: genetic approaches, 2nd ed. CABI Publishing.

Dương Nhựt Long, Lam Mỹ Lan, Nguyễn Anh Tuấn, 2014. Sinh học và kỹ thuật nuôi một số loài cá nước ngọt ở vùngĐồng bằng sông Cửu Long. NXB Lao Động.

Dương Thúy Yên và Phạm Thanh Liêm, 2014. Mối quan hệ giữa kích cỡ và các chỉ tiêu sinh sản của cá rô đầu vuông (Anabas testudineus). Tạp chí Khoa học Trường Đại học Cần Thơ. 34b: 77-83.

Dương Thúy Yên, Dương Nhựt Long, 2013. Ảnh hưởng của nguồn gốc cá bố mẹ đến tăng trưởng và tỉ lệ sống của cá rô (Anabas testudineus Bloch, 1792) giai đoạn ương từ cá bột lên cá giống. Tạp chí Nông Nghiệp và Phát triển Nông thôn. 6: 66-72.

Dương Thúy Yên, Nguyễn Văn Cầu và Dương Nhựt Long, 2017. Quá trình phát triển của nghề nuôi cá trê lai ở các tỉnh đồng bằng sông Cửu Long và nhận thức của người nuôi về vấn đề con lai. Tạp chí khoa họcTrường Đại học Cần Thơ. 50: 91-96.

Einum, S., Fleming, I.A., 1999. Maternal effects of egg size in brown trout (Salmo trutta): norms of reaction to environmental quality. Proc. R. Soc. Lond. B 266: 2095-2100.

Einum, S., Fleming, I.A., 2000. Highly fecund mothers sacrifice offspring survival to maximize fitness. Nature 405, 565-567. 
Heath, D.D., Fox, C.W., Heath, J.W., 1999. Maternal effects on offspring size: Variation through early development of chinook salmon. Evolution 53: 1605-1611

Lê Nguyễn Ngọc Thảo, Trần Đắc Định và Dương Thúy Yên, 2017. Hiện trạng khai thác cá trê vàng (Clarias macrocephalus) ở Đồng bằng sông Cửu Long. Tạp chí khoa họcTrường Đại học Cần Tho. 48b: $18-26$

Na-Nakorn, U., Brummett, R.E., 2009. Use and exchange of aquatic genetic resources for food and aquaculture: Clarias catfish. Rev. Aquac. 1: 214-223.

Nguyễn Văn Kiểm, Lam Mỹ Lan, 2017. Sử dụng Domperidon và $17,20 \mathrm{P}$ kích thích cá trê vàng (Clarias macrocephalus GUNTHER, 1864) sinh sản. Nghiên cứu khoa học và phát triển kinh tế, trường Đại học Tây Đô. 1: 215-223.

Parker, G.A., Begon, M., 1986. Optimal egg size and clutch size: effects of environment and maternal phenotype. Am. Nat. 128: 573-592.

Phạm Minh Thành và Nguyễn Văn Kiểm, 2009. Cơ sở khoa học và kỹ thuật sản xuất cá giống. NXB Nông Nghiệp.

Phạm Thanh Liêm, Nguyễn Hồng Quyết Thắng, Bùi Minh Tâm, 2015. Sinh sản nhân tạo cá trê Phú Quốc (Clarias gracilentus Ng, Hong \& Tu, 2011) bằng các chất kích thích khác nhau. Tạp chí Khoa học Trường Đại học Cần Thơ. 37: 112-119.

R Core Team, 2017. R: A language and environment for statistical computing. R Foundation for Statistical Computing, Vienna, Austria. URL https://www.R-project.org/. 